\title{
The Statistical Relevance and Effect of Assuming Pessimistic Default Overall Thermal Transmittance Coefficients on Dwelling Energy Performance Certification Quality in Ireland
}

\author{
Ciara Ahern \\ Technological University Dublin, ciara.ahern@tudublin.ie \\ Brian Norton \\ Technological University Dublin, brian.norton@tudublin.ie \\ Bernard Enright \\ Technological University Dublin, bernard.enright@tudublin.ie
}

Follow this and additional works at: https://arrow.tudublin.ie/engschcivart

Part of the Construction Engineering Commons

\footnotetext{
Recommended Citation

Ahern, C., Norton, B., \& Enright, B. (2016) The Statistical Relevance and Effect of Assuming Pessimistic Default Overall Thermal Transmittance Coefficients on Dwelling Energy Performance Certification Quality in Ireland, Energy and Buildings, Volume 127, 1 September 2016, Pages 268-278. doi:10.1016/ j.enbuild.2016.05.089
}

This Article is brought to you for free and open access by the School of Civil and Structural Engineering at ARROW@TU Dublin. It has been accepted for inclusion in Articles by an authorized administrator of ARROW@TU Dublin. For more information, please contact arrow.admin@tudublin.ie, aisling.coyne@tudublin.ie, gerard.connolly@tudublin.ie.

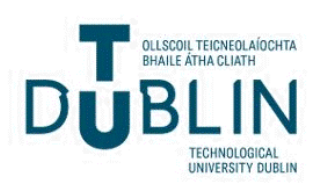




\section{Accepted Manuscript}

Title: The statistical relevance and effect of assuming pessimistic default overall thermal transmittance coefficients on dwelling energy performance certification quality in Ireland.

Author: Ciara Ahern Brian Norton Bernard Enright

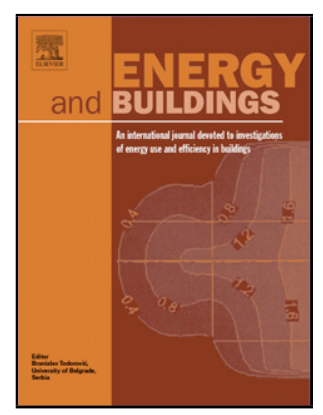

PII: S0378-7788(16)30478-9

DOI: http://dx.doi.org/doi:10.1016/j.enbuild.2016.05.089

Reference: ENB 6724

To appear in: $\quad E N B$

Received date: $\quad$ 15-12-2015

Revised date: 27-5-2016

Accepted date: $\quad 28-5-2016$

Please cite this article as: Ciara Ahern, Brian Norton, Bernard Enright, The statistical relevance and effect of assuming pessimistic default overall thermal transmittance coefficients on dwelling energy performance certification quality in Ireland., Energy and Buildings http://dx.doi.org/10.1016/j.enbuild.2016.05.089

This is a PDF file of an unedited manuscript that has been accepted for publication. As a service to our customers we are providing this early version of the manuscript. The manuscript will undergo copyediting, typesetting, and review of the resulting proof before it is published in its final form. Please note that during the production process errors may be discovered which could affect the content, and all legal disclaimers that apply to the journal pertain. 
The statistical relevance and effect of assuming pessimistic default overall thermal transmittance coefficients on dwelling energy performance certification quality in Ireland.

Author \& Corresponding Author: Ms. Ciara Ahern

Dublin Energy Lab,

Department of Building Services,

School of Mechanical and Design,

Dublin Institute of Technology,

Bolton St.,

Dublin 1

Ireland

Email: ciara.ahern@dit.ie

Tel: 0035314023834

\section{Co Author 1}

Prof. Brian Norton

Dublin Energy Lab,

Dublin Institute of Technology,

Grangegorman,

Dublin 7

Ireland

Email: brian.norton@dit.ie

Tel: 0035314027135

\section{Co Author 2}

\section{Mr. Bernard Enright}

School of Civil and Structural Engineering

Dublin Institute of Technology,

Bolton St.,

Dublin 1

Ireland

Email: bernard.enright@dit.ie

Tel: 0035314023888 


\title{
Highlights
}

- Appraises the necessity of use of pessimistic default U-values in energy labelling.

- Recommends a statistically relevant selection point for default U-values.

- Assesses impact of default use on building performance certification quality.

- Highlights inappropriate use of default U-values as energy model inputs.

- Highlights how default use may impact uptake of residential upgrade measures.

\begin{abstract}
In the EU, Energy Performance Certificates (EPCs) are issued for dwellings whenever they are constructed, sold or leased. Where requiring data would be prohibitively costly, nationally applicable default-values for the thermal transmittance coefficients of the building envelope are employed. Use of such worst case default U-values ensure that a poor dwelling does not attain a better energy rating than is merited. In the absence of empirical data in Ireland thermal-default U-values, as in many other EU member states, are determined by the type and date of construction and then prevailing building codes. Using 463,582 dwellings representing $32 \%$ of the total Irish dwelling stock, this work assesses the relevance of current default U-values. Significant levels of retrofits have been found to lead to the default UValues used now being higher that is typical in reality, thus decreasing the accuracy, and hence credibility, of an EPC. Lack of certification accuracy also inhibits investment in energy efficiency.
\end{abstract}

Keywords: Default U-values, energy performance certification, Irish housing stock, detached house 


\section{Introduction}

Building energy classification allows inter-comparison of building energy use $[1,2]$. The EU Directive on Energy Performance of Buildings (EPBD) [Directive 2002/91/EC] mandates comparable energy performance classifications, in the form of Energy Performance Certificates (EPCs), be issued for buildings constructed, sold or leased across the European Union $[3,4]$. Different approaches to calculating the energy classification of dwellings have been adopted across EU Member States [2, 5]. In Ireland and in the UK the energy classification of a building compares energy consumption and $\mathrm{CO}_{2}$ emissions theoretically calculated for an actual building, with a standardised benchmark building of the same typology and floor area as shown in Eqs. (1) and (2) below [6];

$\frac{\text { Primary Energy Use actual }}{\text { Primary Energy Use benchmark }}=$ Energy Performance Coefficient $\left[\frac{K W h}{m^{2} \cdot \text { annum }}\right]$

$\frac{\mathrm{CO}_{2} \text { Emissions actual }}{\mathrm{CO}_{2} \text { Emissions benchmark }}=\mathrm{CO}_{2}$ Emissions Indicator $\left[\frac{\mathrm{kgCO}_{2}}{\mathrm{~m}^{2} . \text { annum }}\right]$

(2)

An EPC:

- Presents the calculated energy performance coefficient of the building on a scale of A (which should have the lowest fuel bills) to G [2].

- Uses the same scale to define the impact a home has on the environment through greenhouse gas emissions.

In Ireland [7] and in the UK [8] publically-available EPC methodologies are used to calculate the energy classification of dwellings. EPC methodologies at the national level need to have:

- credibility and accuracy so that buildings with better labels should use less energy [2, 9],

- applicability to a wide variety of buildings balancing some loss of accuracy with remaining representative [5],

- clarity so that users should be able to understand a) the overall result and b) the effect of choices (input) on the calculation result $[5,9]$, 
- reproducibility so that for a specific building the underlying method used leads to the same result; irrespective of subjective or arbitrary choices and independent of the user $[2,5]$,

- transparency and encourage improvement to ensure the energy label of a given building is relevant and useful $[2,5,9]$,

- cost-effectiveness

- obtaining the building data needed for an energy performance certificate must not be too labour intensive to avoid significantly adding to the cost of the label particularly compared to the impact of the certificate on the energy performance [5].

- complexity and user skills - avoiding poorly user-interfaced complex simulation programmes that require a high training level for the programme user [10].

The results outputted by EPC methodologies can only offer an estimation of the actual building energy consumption since input data is often based on default operating conditions for inter alia external temperatures, internal loads, system efficiencies, prices and occupancy patterns $[2,9,11-16]$. There can thus be a major gap between the theoretical prediction and actual energy consumed in homes when occupied by real people $[2,11,17]$. In general, and as shown in Fig. 1 theoretical predicted energy consumption tends to be [11];

- Overestimated for average and less energy-efficient dwellings. This is explained partly by the 'prebound effect' [14] wherein occupants consume 30\% less heating energy on average than the theoretical predicted rating, and

- $\quad$ underestimated when observing new or retrofitted dwellings. This is explained partly by the 'rebound effect' [18] wherein thermally retrofitted dwellings enable higher internal comfort temperatures more affordable leading to increased energy consumption rather than reduced energy bills [11, 19-22].

Eqs. (1) and (2) show that the benchmarking process is a comparative analysis [2] that also informs an associated advisory report recommending feasible energy efficiency measures from both technical and economical perspectives $[2,9,15]$. The underlying premise being that a householder decisions are predicated on financial savings. Informing the household about cost-effective energy-saving measures is anticipated therefore to result in marked 
behavioural change to reduce their energy costs $[23,24]$. However even when the majority of recommendations are economically advantageous, consumers are not generally persuaded to act rationally to adopt these measures [23-25]. A barrier perceived by homeowners is inaccuracy wherein the financial savings in reality smaller that the label estimates [17]. To overcome this barrier energy consumption associated with improving an EPC label after a specific energy saving intervention in a particular dwelling should reflect closely the actual decrease in energy consumption $[3,11]$. The effectiveness of the rating therefore depends on the proper selection of default data $[2,13]$. Where accurately obtaining all of the required building envelope data would be excessively labour-intensive and/or invasive, national default values are sometimes employed. Default values are normally pessimistic so as to [5];

- avoid offering a better than merited energy rating,

- allow the homeowner to know the energy advantage of carrying out retrofits,

- encourage the homeowner to maintain records of energy upgrades that inform EPCs, and

- encourage assessors to seek out information to improve the energy rating.

An illustrative case of two identical buildings is examined in Table 1 [5]. Where for one building the data item is not observable on site or via documentary evidence so a default is used, while for the other building the actual data available was used.

Information on the thermal characteristics of older dwellings is often more difficult to obtain than for recently constructed dwellings. If an improvement in the energy performance certification is the basis for renovation, use of pessimistic default values may lead to higher improvement expectations in the EPC rating [5, 11]. Arkestijn and van Dijk (2010) [5] raised the policy-related question of whether it is fair to give a worse energy rating simply because less information is available. Furthermore, if the lack of information associated with the building is to be penalised - how tough should the penalty be? In other words how pessimistic should the default value be?

A thermal transmittance coefficient or U-value of a building element is the rate of heat transfer (in watts) through one square meter of the building element divided by the difference in temperature across the element structure expressed in $\mathrm{W} / \mathrm{m}^{2} \mathrm{~K}$. The $\mathrm{U}-\mathrm{V}$ alue is used to inform the heat energy consumption characteristic of a dwelling. The optimum choice of a default U-value characteristics should be based on empirical evidence. In the absence of such 
empirical data and as shown in Table 2, Irish thermal default U-values (similar to many other EU member states) were determined from [26, 27];

- building element type,

- the date of construction for pre-thermal regulation dwellings (pre-1978).

- prevailing draft or finalised building codes by period of construction for post-thermal regulation dwellings (1978 - 2006) - allowing a grace period of generally two to three years after a proposed change in draft or finalised regulations for a dwelling to be completed [27].

Ireland [28, 29] along with Italy [30], Spain [31] and Austria [32] use methodologies to calculate residential stock energy consumption using default U-Values applied to equally default dwelling typologies classified by period of construction. The objectives of this work are to use the recently published Irish national empirical energy performance certification database [33] and SPSS ${ }^{\circledR}$ software, to:

- Assess the relationship of current default U-Values relative to the empirical statistical distribution.

- Make recommendations for updated default U-value's relative to the empirical statistical distribution.

- Discuss the potential impact of default U-Value selection on the validity of,

- energy performance certification,

- use of default U-values as key inputs to national building energy consumption models.

- Highlight the potential contribution of their use to prebound effect in existing dwellings

\section{Case Study - The housing stock of Ireland}

\subsection{Context}

As can be seen in Fig 2, rural detached, oil-heated dwellings, Ireland's predominant house typology, comprises $18 \%$ of the total dwelling stock. This dwelling typology makes a good case study dwelling as; 
- it qualifies as a reference dwelling under the European Commission delegated regulation no. 244/2012 [34],

- shown in Fig. 3, whilst Ireland has the highest proportion of single family dwellings in Europe [35] it is not extraordinary in this regard. Countries such as The UK, Greece, Norway and The Netherlands have similar profiles.

- $34 \%$ of the EU 28 population lived in detached houses in 2013 [36].

- $67 \%$ of European housing was built prior to 1980 [37] and the introduction of meaningful thermal regulation of the housing sector. Mirroring this, $70 \%$ of Irish detached dwellings were constructed before the mid 1970's when constructional changes caused primarily by amendments to draft or actual thermal regulations led to increased levels of thermal insulation in Irish dwellings [27, 28, 38].

\subsection{Methodology}

EPCs in Ireland are generated through a methodology embodied in the national Dwelling Energy Assessment Procedure (DEAP) software programme administered on behalf of the state by the Sustainable Energy Authority of Ireland (SEAI). SEAI made this detailed national empirical dataset publicly available in 2014 [39]. 463,582 dwellings representing $31.7 \%$ of the total dwelling stock constructed up to 2006 received an EPC by August 2014 [33]. Rural, detached, single and two-storey, oil centrally-heated and naturally-ventilated dwellings were isolated from the larger dataset. Dwellings carrying a 'provisional' certificate were also filtered. As shown in Table 3, this resulted in a sample of 50,236 dwellings representing $11 \%$ of the available database. Table 2 shows that the refined dataset compares well with the national distribution of detached dwellings by date of construction [27]. Due to older dwellings changing ownership less often, EPCs have been carried out on older dwellings less frequently than newer housing. Newly-constructed detached dwellings are thus more represented in the empirical dataset [33].

Fig 4 (a) shows an illustrative typical U-value frequency distribution for a real thermal building element extracted from the Irish national empirical dataset using SPSS ${ }^{\circledR}$ software [33]. The frequency distribution reveals the thermal characteristics of Ireland's reference dwelling envelope to be normally bi-modally distributed with "Mode 2" reducing relative to "Mode 1" likely due to retrofit interventions. The position of current default value relative to 
the statistical distribution was examined. Statistical probability tests performed found the default value to often have no statistical significance to the empirical distribution. Moreover, as more retrofit interventions are carried in the housing sector current defaults become less relevant to the real statistical distribution over time especially with respect to "Mean 1". The default U-value was thus filtered from the database and hence the solver tool in EXCEL ${ }^{\circledR}$ was used to employ the method of maximum log likelihood as the best method [40] for estimating the best fit curve for probability distribution of large datasets. Fig. 4 (b) shows how a curve was fitted to the real data. Thermally upgraded or Mode $1 \mathrm{dwellings} \mathrm{show} \mathrm{a} \mathrm{tighter} \mathrm{and} \mathrm{more}$ pronounced distribution profile than Mode 2 dwellings which have yet to undergo significant thermal upgrades. In general and as illustrated in Fig.4 (b), the standard deviation for Mode 2 tends to be greater than that of Mode 1; this is attributed to thermal retrofits achieving a more harmonised level of thermal insulation.

\subsubsection{How pessimistic should the default U-Value be?}

If it is accepted that pessimistic default U-values should be employed when producing EPC's to (i) keep the cost of certification at an affordable level and, (ii) aid the reproducibility and robustness of the method for situations where information is lacking. When selecting how pessimistic default U-Values should be, the key issue, is the potential impact of that selection point on the EPCs accuracy. Table 4 discusses the implications whilst Figure 5 outlines the scale of default selection options relative to a normalised statistical distribution of a dwelling elements thermal characteristic.

Table 4 outlines how the selection of;

a) 'moderately optimistic' to 'very optimistic' default U-values are not desirable as it may act as a disincentive to carrying out thermal energy efficiency upgrades in the housing sector,

b) 'Very pessimistic' default U-values are likewise not desirable due to the significant risk of

i. greatly overestimating the potential saving from retrofit intervention and

ii. the creation of a very punitive system for existing dwellings where information is often difficult to obtain. 
c) 'Realistic' statistically derived means will often lead to an underestimation of the potential to improve the energy performance rating.

'Moderately pessimistic' and 'pessimistic' thus remain. Fig. 5 shows how the use of;

d) 'moderately pessimistic' default U-values ( $50^{\text {th }}$ to $84.1^{\text {st }}$ percentile point $)$, results in a slight loss of validity and a better comparative energy performance rating of the two identical buildings examined in Table 1, however there is significant risk of overestimating the potential savings from a retrofit intervention for dwellings occupying the $84.1^{\text {st }}$ to $100^{\text {th }}$ percentile point $(15.9 \%$ of the dwelling stock assuming a normal distribution).

e) 'pessimistic' default U-values $\left(84.1^{\text {st }}\right.$ to $97.7^{\text {th }}$ percentile point) will lead to a greater loss in validity than that of moderately pessimistic U-values, but only a slight risk of overestimating the potential savings from a retrofit intervention for dwellings occupying the tail of the distribution (15.9 to $6.7 \%$ of the dwelling stock).

Assuming the empirical data to distribute normally, it is relatively straightforward to pick a 'reasonably pessimistic' default U-value between the $85^{\text {th }}$ or $90^{\text {th }}$ percentiles as shown in Fig. 5. Selection of a default U-Value in this zone will ensure a reasonable level of accuracy for the certificate but also allow the home-owner to perceive the energy advantage of carrying out thermal retrofits. As Mode 2 dwellings are yet to engage in upgrade measures, Mode 2 is the relevant mode for analysis to recommend empirically derived defaults U-values. The dataset [33] was thus analysed to recommend default U-values based on the $90^{\text {th }}$ percentile point of the Mode 2 distribution - assuming it accounted for a meaningful proportion of the dwelling stock.

\subsection{Results}

\subsubsection{Position of current defaults relative to average empirically derived (real) U-Values}

Pre-thermal regulation building elements are generally assumed to be have been originally constructed without insulation [27]. Fig. 6 demonstrates that building energy assessors were often able to identify the presence of insulation in pre-thermal regulation dwellings, demonstrated by the gap between the maximum regulation default wall U-value and the real mean U-values by period of construction. The data indicates that end-users either;

(i) constructed to better specifications than required by thermal regulation prevailing at the time or

(ii) have carried out autonomous energy-efficiency improvements 
Greater deviation from the current default wall U-values is observed in pre-thermal regulation dwellings constructed pre-1900 and up and until circa 1978. A high degree of autonomous energy-efficiency improvements is noted in dwellings constructed between 1950 and 1977. These dwellings were found to have the worst heat loss characteristics within this typology, which may have provided greater motivation for the end-user to invest in upgrade measures [28]. In post-regulation dwellings constructed between 1978 and 2006; and as time progresses the disparity between the default and real U-value lessens. Notably however, in the period between 2005 to 2006,6 to $7 \%$ of dwelling walls surveyed were not compliant with the prevailing thermal regulations. This may be attributable to a lax adherence to building control measures during Ireland's recent housing construction boom [41].

In 2014, $58 \%$ of walls and $64 \%$ of roofs were found to have significant levels of insulation; an increase from $3 \%$ and $7 \%$ in 2001 - 2002 [42]. Roof U-values range from 0.13 to 0.29 $\mathrm{W} / \mathrm{m}^{2} \mathrm{~K}$ and, as shown in Fig. 7, do not significantly vary by period of construction. Roof Uvalues are generally lower than wall U-Values; wall U-values range from 0.15 to 0.41 $\mathrm{W} / \mathrm{m}^{2} \mathrm{~K}$ for pre-thermal regulation dwellings (with the exception of pre-1900 two-storey walls at $1.13 \mathrm{~W} / \mathrm{m}^{2} \mathrm{~K}$ ) and 0.28 to $0.31 \mathrm{~W} / \mathrm{m}^{2} \mathrm{~K}$ for post-thermal regulation dwellings. The improved thermal characteristic of roofs is attributable to the relative ease and lower cost of retrofitting attic insulation compared to wall insulation.

Figures 6 and 7 demonstrate that;

(i) the strong association of a dwellings age with its energy efficiency is diminishing as retrofits in the sector are carried out, and

(ii) the use of pessimistic default thermal characteristics as inputs to national energy consumption models considerably overestimates the energy saving potential of the existing housing stock.

\subsubsection{Assessment of level of thermal retrofits for Ireland's predominant housing typology}

The percentage of significantly retrofitted or Mode 1 dwellings by period of construction and building type is presented in Table 5. Table 5 indicates that $44 \%$ of walls and $47 \%$ of roofs in pre-thermal regulation dwellings have undergone significant thermal retrofits, whilst $71 \%$ of walls and $80 \%$ of roofs in post-thermal regulation dwellings have either undergone 
autonomous energy efficiency upgrades or were constructed to better the maximum allowable U-value of the time.

\subsubsection{Recommendation to revise default U-Values}

Due to the difficulty of (i) retrofitting floor insulation in an occupied dwelling [28], and (ii) identifying the presence of floor insulation retrospectively, the empirical database did not reveal any thermal upgrades of floors. Table 6 thus presents recommendations for walls and roofs only. The thermal performance of single storey and two-storey dwellings - with the same thermal characteristics - will differ owing to a different volume to surface area ratio. One and two-storey dwellings are thus distinguished.

Irish thermal default U-values, similar to many other EU member states, were determined;

(i) from the type and date of construction for pre-thermal regulation elements and;

- Walls - Recommendations for updated default U-values in table 6 reasonably approximate current default U-value of $2.1 \mathrm{~W} / \mathrm{m}^{2} \mathrm{~K}$. A small average reduction of $10 \%$ of the ratio of standard deviation over the mean or Relative Standard Deviation (RSD) for single-storey walls and - $8 \%$ RSD for two-storey walls is thus recommended.

- Roofs - Recommendations for updated default U-values in table 6 deviate significantly from the current default $\mathrm{U}$-value of $2.3 \mathrm{~W} / \mathrm{m}^{2} \mathrm{~K}$. An average reduction - $60 \%$ RSD for single-storey roofs and - $38 \%$ for two-storey roofs is thus recommended. The difference between single and two-storey dwellings might be attributed to the fact roof surface area on single storey dwellings impacts the dwelling heat loss characteristic to a much greater extent than in the equivalent two storey-dwelling. This may have provided more motivation to the home- owner to carry out thermal upgrades to this element.

(ii) by the maximum allowable $U$-value at time of construction for post-thermal regulation elements;

- Walls - Pre-thermal regulation single and two-storey walls behave similarly; however post-thermal regulation, single-storey dwelling walls tend to perform better thermally than their two-storey counterpart. Therefore an average reduction of - $19 \%$ RSD to the current thermal default is recommended for single-storey 
detached dwellings while an average - $7 \%$ RSD reduction is recommended for two-storey walls. Dwellings constructed between 1978 and 1982 see the largest deviation of 30 and $14 \%$ for one and two-storey dwellings respectively, this may be attributable to the 1979 oil crisis making people more aware of the value of insulation and the positive effect of the draft thermal building regulations published in the mid 1970's.

- Roofs - post-regulation, roofs show a better approximation to the current default with an average RSD of +/- 11 and $10 \%$ for single and two-storey dwellings respectively. Oddly between 2000 and 2006 the recommended defaults are greater than the current defaults, this is also attributed to a lax adherence to building control measures during Ireland's recent housing construction boom [41].

\section{Discussion \& Recommendations}

The building sector, and especially pre-existing housing, is often identified as providing 'enormous' $[43,44]$ potential for $\mathrm{CO}_{2}$ reduction. Monitoring of the energy performance of the building stock has generally provided knowledge, analysis and evidence insufficient to $[11,35]$;

- track the progress and impact of policy implementation,

- make comparisons between different policy and market regulatory environments,

- recommend best practice to achieve energy efficient buildings.

This results work highlights how use of pessimistic default thermal characteristics as inputs to national energy consumption models will cause the model to considerably overestimate the energy saving potential of the existing housing stock for pre-regulation dwellings (prebound effect). The practice of employing default characteristics in energy consumption models questions whether $[14,17,22]$;

- the energy saving potential of the building sector is as large as previously thought and

- the burden for $\mathrm{CO}_{2}$ reductions on this sector is realisable.

Ambitious $\mathrm{CO}_{2}$ reduction targets exist for the existing housing stock [2, 14, 35]. EPC databases are rich in information that represents a significant opportunity to contemporaneously inform empirically derived residential energy consumption models. Gathering the information necessary to populate an EPC database is also expensive and labour intensive. The inclusion of pessimistic defaults in resultant EPC databases means that 
these rich databases cannot act as an accurate tool for monitoring the energy consumption of the dwelling stocks in line with the original intention of the EPBD directive. It is strongly recommended that intelligent databases should continually analyse EPC data to produce empirically derived housing typologies, by period of construction and by percentage of the dwelling stock applying - Mode 1 and Mode 2 as shown in Fig.4 (b). These databases then more accurately inform national residential energy consumption models and policies thus narrowing the energy performance gap.

To further highlight the impact of use of default model inputs and virtual dwelling typologies on the prebound effect; a sensitivity analysis to the use of statistically derived mean U-values to residential energy consumption models is recommended. Ireland's national EPC empirical dataset could be exploited to create a real validated reference dwelling typology by period of construction for Ireland's predominant housing typology. The resulting data can hence be used as simplified and validated inputs to a bottom-up residential energy consumption models.

In order to produce (i) a building energy label, (ii) recommend energy efficiency measures and (iii) calculate payback periods; a typical EPC calculation engine for dwellings compares the predicted energy consumption of the actual dwelling with that of a standardised benchmark building of the same typology as shown in Eqs. (1) and (2) and Fig. 8.

As discussed in Section 1.0, where defaults are employed the program will return unrealistically short payback periods for refurbishment works. To,

(i) remove this known barrier to the uptake of energy efficiency upgrades in the residential sector and,

(ii) allow the end user to make a more informed decision on retrofitting strategies, reports of the assessor should highlight how building element U-Values were determined, how accurate they believe those values to be and carry out a sensitivity analysis highlighting the impact their assumptions may have on the energy label and/or potential energy savings resulting from thermal retrofits. To produce a range of results in this analysis, it is recommended that a typical Mode 2 dwelling by period of construction be characterised to replace the actual dwelling of Eqs. (1) and (2) as shown in Fig. 8 and as described by Eqs.(3) and (4) below: 
$\frac{\text { Primary Energy Use Mode } 2 \text { Typical }}{\text { Primary Energy Use Benchmark }}=$ Energy Performance Coefficient $(E P C)\left[\frac{K W h}{m^{2} . \text { annum }}\right]$

(3)

Typical paybacks achieved through refurbishment measures by period of construction could also be indicated as shown below;

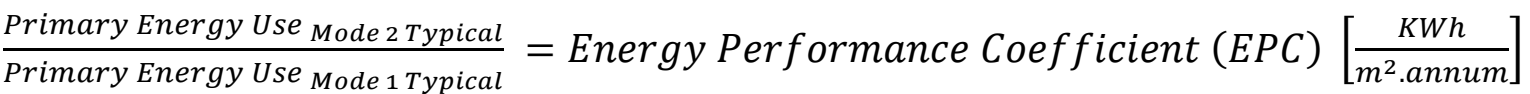

The consequent realistic payback periods, increase the credibility of the advisory report associated with the EPC.

\section{Conclusions}

Analysis of Ireland's predominant housing typology in 2014 finds $58 \%$ of walls and $64 \%$ of roofs to have significant levels of insulation; an increase from $3 \%$ and $7 \%$ in $2001-2002$. The results indicate that $44 \%$ of walls and $47 \%$ of roofs in pre-thermal regulation dwellings have undergone significant thermal retrofits, whilst $71 \%$ of walls and $80 \%$ of roofs in postthermal regulation dwellings have either undergone autonomous energy efficiency upgrades or were constructed to better the maximum allowable U-value of the time. These significant levels of thermal retrofits in Irish housing sector are leading to;

- a diminishing association between a dwellings age and its energy efficiency,

- a positively shifting bi-modal distribution of thermal characteristics,

- default U-Values chosen as described in Section 1.0, have become increasing outmoded.

The use of outmoded default U-Values to necessarily maintain the cost-effectiveness of EPC decreases the accuracy and hence credibility of both the EPC and its associated advisory report. A perceived lack of certification accuracy by the homeowner inhibits investment in energy efficiency.

Adoption of "reasonably pessimistic" statistically relevant default U-Values shall underrank the performance of circa $90 \%$ of dwellings and, where used, is assumed to be a significant contributing factor to the prebound effect in dwellings. 


\section{References}

[1] T. Nikolaou, D. Kolokotsa, A. Apostolou, C. Munteanu, Managing Indoor Environments and Energy in Buildings with Integrated Intelligent Systems, Green Energy and Technology, in, Springer International Publishing, Switzerland, 2015.

[2] L. Pérez-Lombard, J. Ortiz, R. González, I.R. Maestre, A review of benchmarking, rating and labelling concepts within the framework of building energy certification schemes, Energy and Buildings, 41 (3) (2009) 272-278.

[3] EU, Energy performance of buildings $* * *$ II, in: P5_TA(2002)0459, The European Parliament, Brussels, 2002.

[4] EU, Accompanying document to the PROPOSAL FOR A RECAST OF THE ENERGY PERFORMANCE OF BUILDINGS DIRECTIVE (2002/91/EC) SUMMARY OF THE IMPACT ASSESSEMENT in: E. Commission (Ed.) COM (2008) 780 final, SEC (2008) 2864, European Commission, Brussels, Belgium, 2002.

[5] K. Arkesteijn, D. van Dijk, Energy performance certification for new and existing buildings - Differences in approach, the role of choice in CEN standards application, in, CENSE, The Netherlands, (http://www.buildup.eu/sites/default/files/content/P156_EN_CENSE_New_and_existi ng buildings.pdf ), 2010, (accessed April 2015)

[6] SEAI, Non-domestic energy assessment procedure (NEAP) Modelling Guide \& SBEM Technical Manual version 3.5.a, in, SEAI, Dublin, Ireland, (http://www.seai.ie/Your_Building/BER/Non_Domestic_buildings/Download_SBEM Software/SBEM\%20Technical\%20Manual\%20V3-4a\%20Oct\%202009.pdf), 2010, (accessed June 2015).

[7] SEAI, Dwelling Energy Assessment Procedure (DEAP), in: Irish official method for calculating and rating the energy performance of dwellings, Version 3.2.1, SEAI, Dublin, Ireland, http://www.seai.ie/Your_Building/EPBD/DEAP/, 2012.

[8] DCLG_UK, English Housing Survey, in: D.f.C.a.L. Government (Ed.), Department for Communities and Local Government, London, UK, 2013.

[9] J.R. Stein, A. Meier, Accuracy of home energy rating systems, Energy, 25 (4) (2000) 339-354.

[10] L. Pérez-Lombard, J. Ortiz, C. Pout, A review on buildings energy consumption information, Energy and Buildings, 40 (3) (2008) 394-398.

[11] D. Majcen, L.C.M. Itard, H. Visscher, Theoretical vs. actual energy consumption of labelled dwellings in the Netherlands: Discrepancies and policy implications, Energy Policy, 54 (0) (2013) 125-136. 
[12] Y.G. Yohanis, J.D. Mondol, A. Wright, B. Norton, Real-life energy use in the UK: How occupancy and dwelling characteristics affect domestic electricity use, Energy and Buildings, 40 (6) (2008) 1053-1059.

[13] J.L. Míguez, J. Porteiro, L.M. López-González, J.E. Vicuña, S. Murillo, J.C. Morán, E. Granada, Review of the energy rating of dwellings in the European Union as a mechanism for sustainable energy, Renewable and Sustainable Energy Reviews, 10 (1) (2006) 24-45.

[14] M. Sunikka-Blank, R. Galvin, Introducing the prebound effect: the gap between performance and actual energy consumption, Building Research \& Information, 40 (3) (2012) 260-273.

[15] SEAI, Introduction to DEAP for professionals, in, SEAI, Dublin, Ireland, 2013.

[16] D. Hull, B.P. Ó Gallachóir, N. Walker, Development of a modelling framework in response to new European energy-efficiency regulatory obligations: The Irish experience, Energy Policy, 37 (12) (2009) 5363-5375.

[17] K. Gram-Hanssen, Retrofitting owner-occupied housing: remember the people, Building Research \& Information, 42 (4) (2014) 393-397.

[18] P.H.G. Berkhout, J.C. Muskens, J. W. Velthuijsen, Defining the rebound effect, Energy Policy, 28 (6-7) (2000) 425-432.

[19] K.J. Lomas, Carbon reduction in existing buildings:a trandisciplimary approach, Building Research and Information, 38 (1) (2010) 1-11.

[20] J.P. Clinch, J.D. Healy, Valuing improvements in comfort from domestic energyefficiency retrofits using a trade-off simulation model, Energy Economics, 25 (5) (2003) 565-583.

[21] J.P. Clinch, J.D. Healy, Alleviating fuel poverty in Ireland, a program for the 21st century, International Journal of Housing Science, 23 (4) (1999) 203-215.

[22] H. Herring, Energy efficiency — a critical view, Energy, 31 (1) (2006) 10-20.

[23] P. Tuominen, K. Klobut, Deliverable 3.1 Country Specifc Factors - Report of Findings in WP3, in: IDEAL - EPBD, VTT Technical research Centre of Finland, Finland, (https://www.bre.co.uk/filelibrary/pdf/projects/country_specific_factors.pdf). 2009, (accessed March 2015).

[24] K. Gram-Hanssen, F. Bartiaux, O. Michael Jensen, M. Cantaert, Do homeowners use energy labels? A comparison between Denmark and Belgium, Energy Policy, 35 (5) (2007) 2879-2888.

[25] T.H. Christensen, K. Gram-Hanssen, M. de Best-Waldhober, A. Adjei, Energy retrofits of Danish homes: is the Energy Performance Certificate useful?, Building Research \& Information, 42 (4) (2014) 489-500. 
[26] R. Lowe, Addressing the challenges of climate change for the built environment, Building Research \& Information, 35 (4) (2007) 343-350.

[27] SEAI, Dwelling Energy Assessment Procedure (DEAP), in: Irish official method for calculating and rating the energy performance of dwellings, Version 3.2.1, SEAI, Dublin, Ireland, 2012.

[28] C. Ahern, P. Griffiths, M. O'Flaherty, State of the Irish Housing stock - Modelling the heat losses of Ireland's existing detached rural housing stock \& estimating the benefit of thermal retrofit measures on this stock, Energy Policy, 55 (2013) 139-151.

[29] M. Badurek, M. Hanratty, W. Sheldrick, TABULA Scientific Report, Ireland, in, Energy Action, Dublin, Ireland, (http://episcope.eu/fileadmin/tabula/public/docs/scientific/IE_TABULA_ScientificRe port_EnergyAction.pdf ), 2012, (accessed April 2014).

[30] T. Loga, N. Deifenbach, B. Stein, R. Born, TABULA - Scientific Report Germany Further Development of the German Residential Building Typology, in, Institut Wohnen and Umwelt, Darmstadt, Germany, (http://www.buildingtypology.eu/downloads/public/docs/scientific/DE_TABULA_ScientificReport_IWU. pdf), 2012, (accessed June 2015).

[31] Ortega, Use of Building Typologies for Energy Perofmane Assessment of National Building Stock - Existent experiences in Spain, in, Valencian Institute of Building, Valencia, $\quad$ Spain, (http://episcope.eu/fileadmin/tabula/public/docs/scientific/ES_TABULA_Report_IVE .pdf), 2011.

[32] M. Amtmann, TABULA - Reference buildings - The Austrian building typology, in, Austrian Energy Agency, Vienna, Austria, (http://episcope.eu/fileadmin/tabula/public/docs/scientific/AT_TABULA_ScientificR eport_AEA.pdf ), 2010, (accessed April 2015). [33] C. Ahern, National BER research tool, in: SEAI (Ed.), SEAI, Dublin, Ireland, 2014.

[33] C. Ahern, National BER research tool, in: SEAI (Ed.), SEAI, Dublin, Ireland, http://www.seai.ie/Your_Building/BER/National_BER_Research_Tool/, Accessed 2014.

[34] EU, Guidelines accompanying Commission Delegated Regulation (EU) No. 244/2012 of 16 January 2012 supplementing Directive 2010/31/EU of the European Parliament and of the council on the energy performance of buildings by establishing a comparative methodology framework for calculating cost-optimal levels of minimum energy performance requirements for buildings and building elements., Official Journal of the European Union, (2012).

[35] M. Economidou, B. Atanasiu, C. Despret, J. Maio, I. Nolte, O. Rapf, Europe's buildings under the microscope - A country-by-country review of the energy performance of buildings, in, Buildings Performance Institute Europe (BPIE), Brussels, Belgium, (http://www.institutebe.com/InstituteBE/media/Library/Resources/Existing\%20Buildi 
ng\%20Retrofits/Europes-Buildings-Under-the-Microscope-BPIE.pdf) 2011. (accessed Feb, 2015).

[36] Eurostat, Housing Statistics, in, 2015.

[37] ENTRANZE, Online Data Tool, in, Energy Economics Group, Vienna, Austria, (http://www.entranze.eu/tools/interactive-data-tool), 2014, (accessed June 2015) [75] M. Norris, P. Shiels, Regular National Report on Housing Developments in European Countries Synthesis Report in: H.a.L.G.I. Department of the Environment (Ed.), www.housingunit.ie, Dublin, Ireland, 2004.

[38] CSO, Census of population, in, www.cso.ie, Central Statistics Office, 2006.

[39] SEAI, National BER Research Tool, in, 2014.

[40] P.G. Hoel, Introduction to mathematical statistics, in: Wiley Series in probability and mathemathical statistics, Wiley \& Sons, Inc., canada, 1984.

[41] Government_of_Ireland, Construction 2020 - A strategy for a renewed construction sector, in, Government Publications, Dublin, Ireland, (http://www.merrionstreet.ie/en/wp-content/uploads/2014/05/Construction-Strategy14-May-20141.pdf), 2014, (access June 2015).

[42] INSHQ, Irish National Housing Survey of Ireland, in: E.a.S.R. Institute (Ed.), 20012002.

[43] EU, Energy efficient buildings save money: Recast of the Energy Performance of Buildings Directive, in: EU (Ed.) MEMO/08/693, Brussels, 2008.

[44] I. Ballarini, S.P. Corgnati, V. Corrado, Use of reference buildings to assess the energy saving potentials of the residential building stock: The experience of TABULA project, Energy Policy, 68 (0) (2014) 273-284. 
Fig. 1 How the prebound and rebound effects may limit energy saving to be less than envisaged [14]

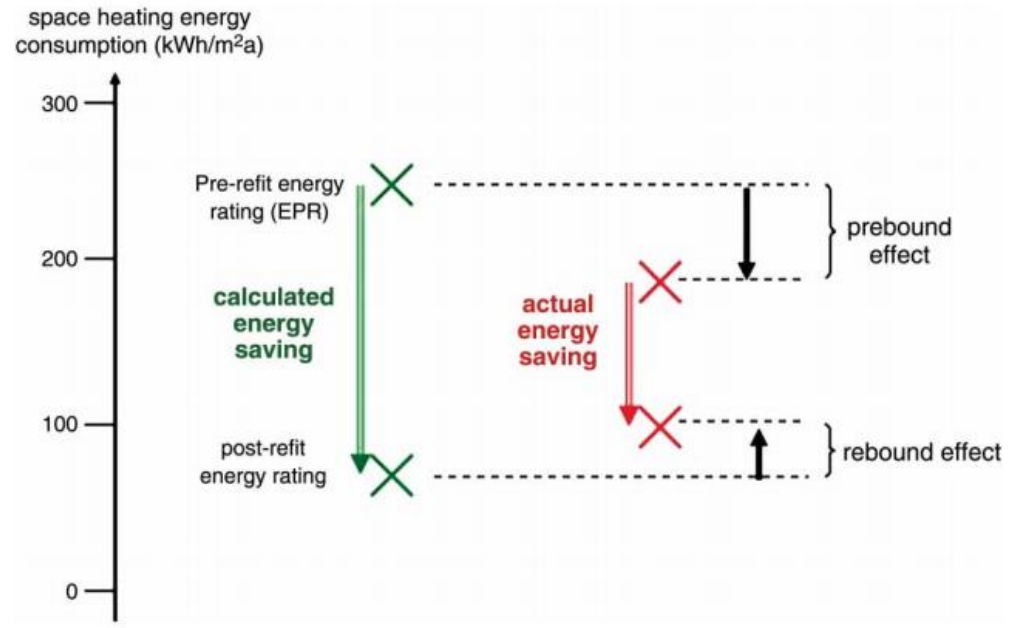

Fig. 2 Number of Irish dwellings by type [38]

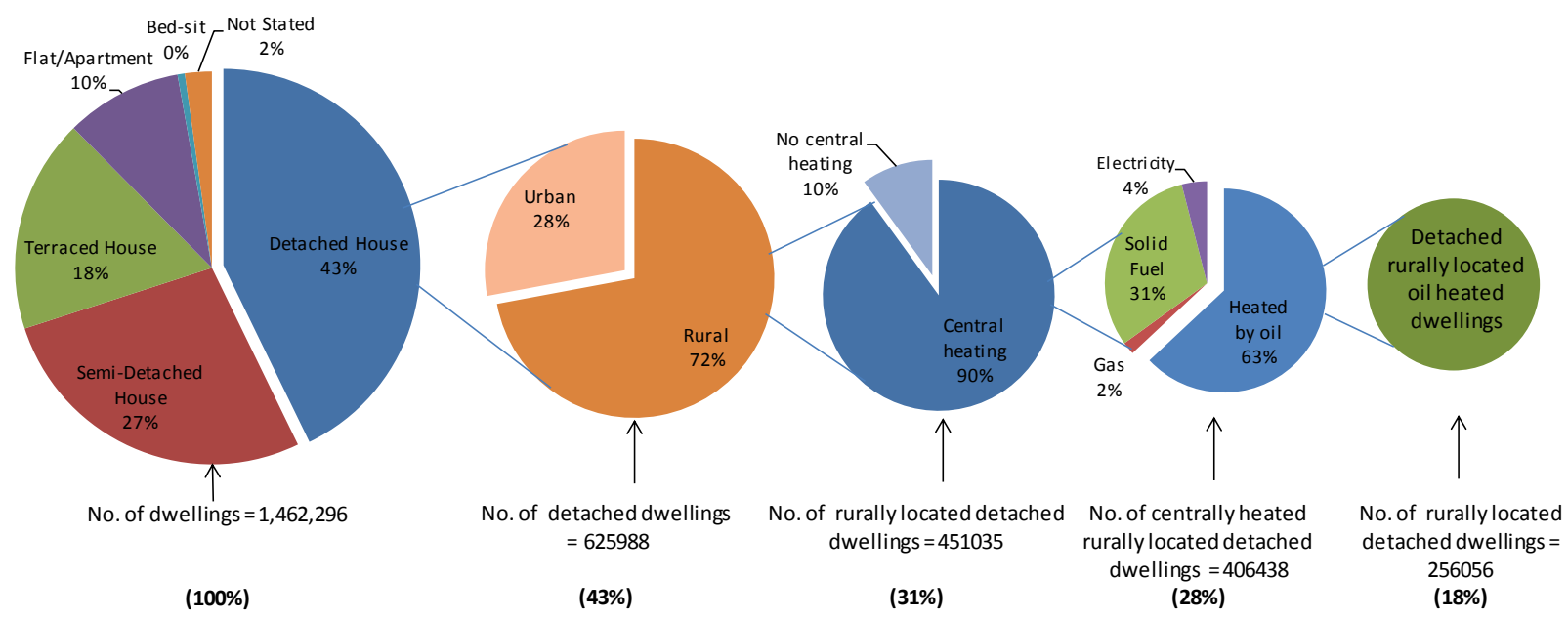


Fig. 3 Single family and apartment buildings in Europe [35]

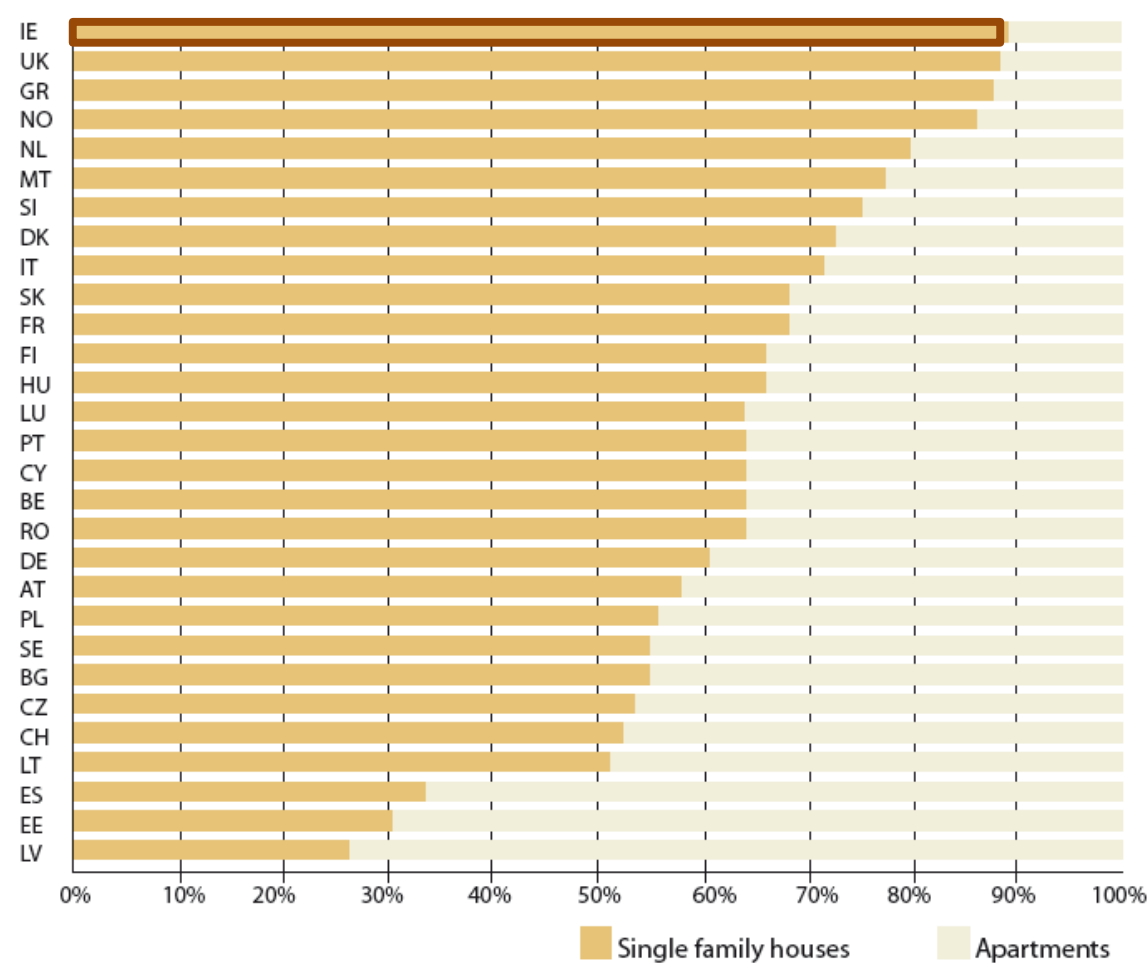


Fig. 4 a \& b Illustrative typical frequency distribution and analysis of wall and roof $U$ values [33]

(a) Illustrative typical frequency distribution

(b) Method of maximum log likelihood applied

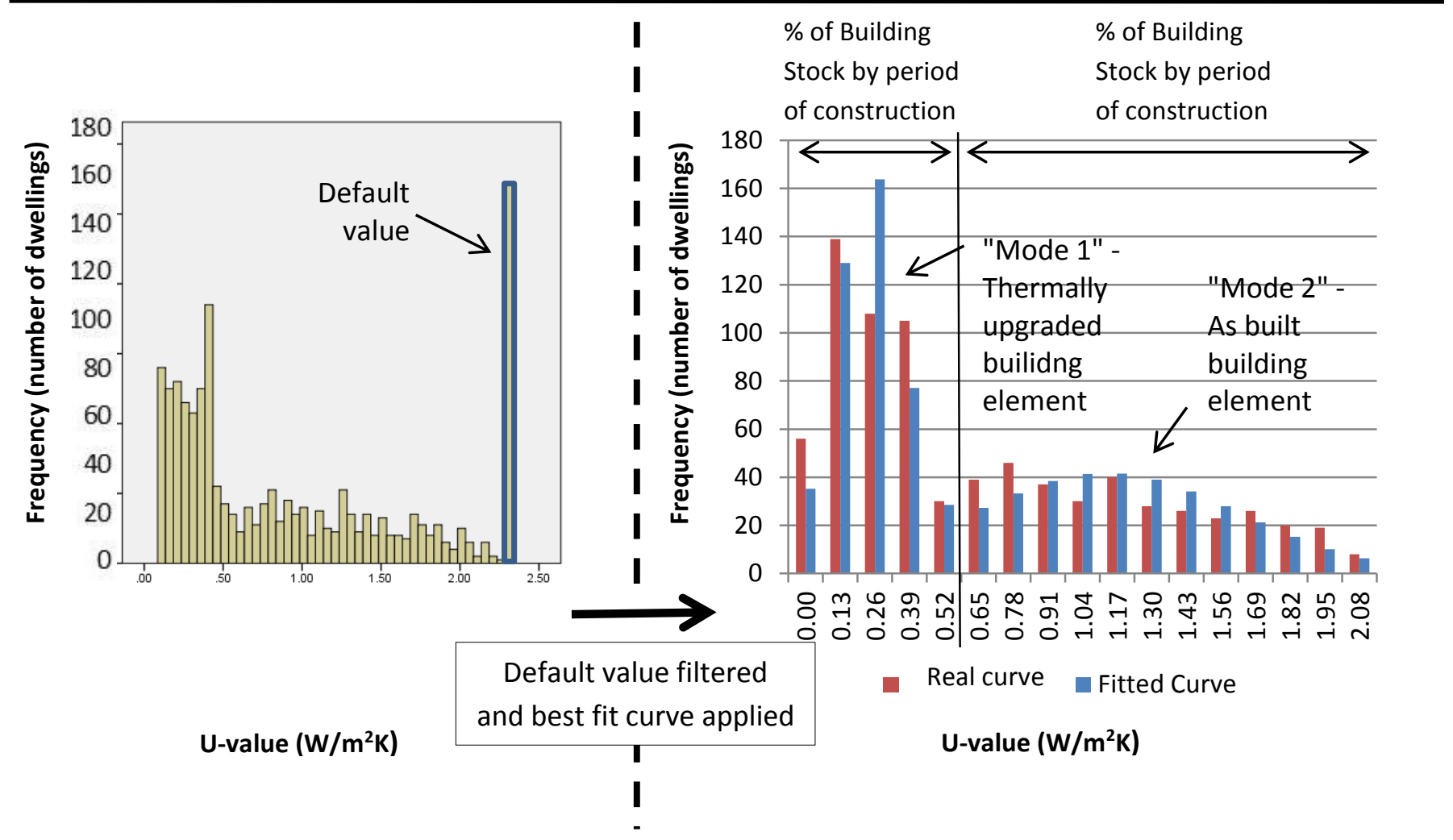


Fig. 5 Relationship of default $U$-value selection to quality aspects of energy performance certification relative to normal statistical distribution

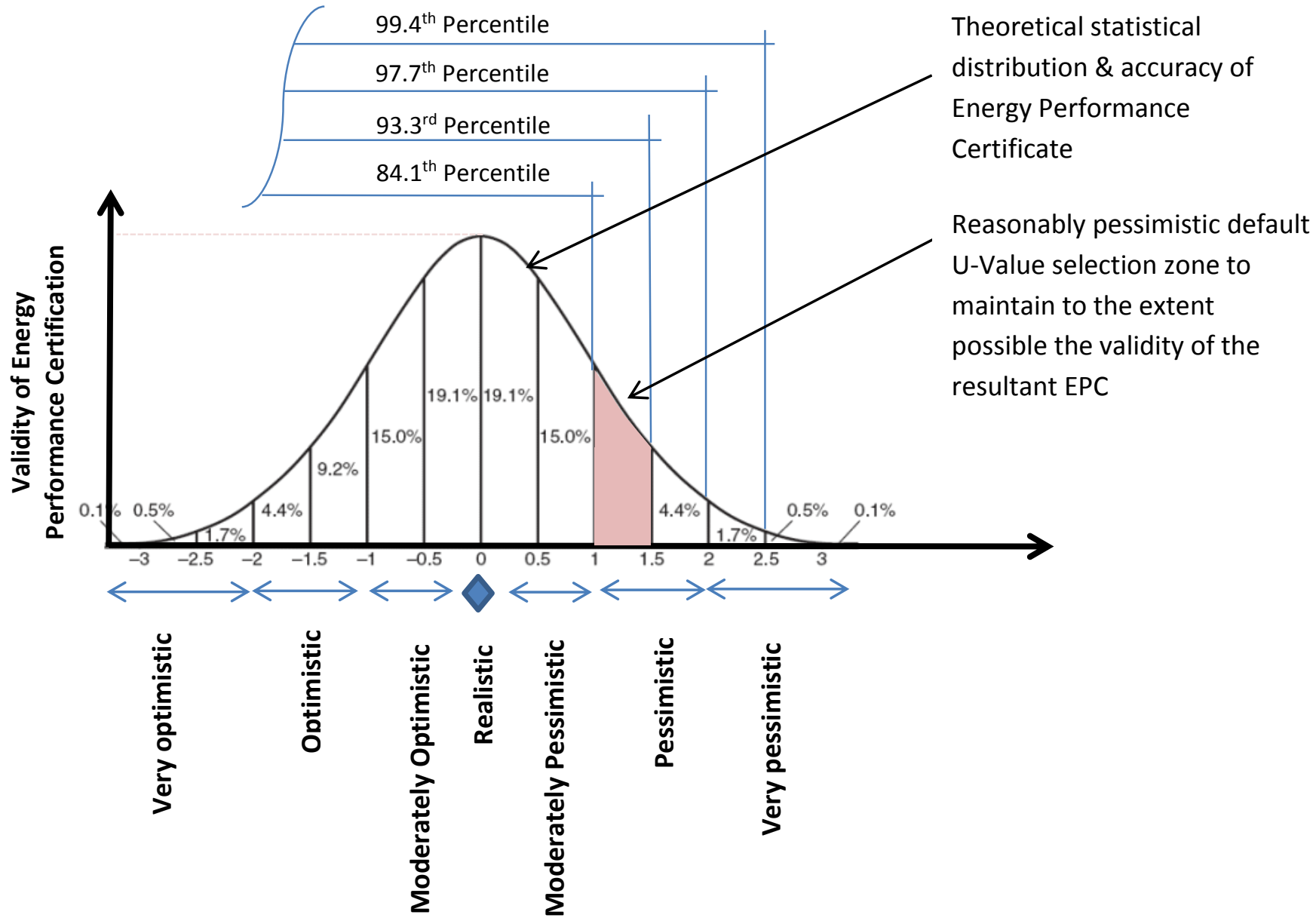

PERCENTILE RANK OF DEFAULT U-VALUE SELECTION $\left(\mathrm{W} / \mathrm{m}^{2} \mathrm{~K}\right)$ 
Fig. 6 Average wall $U$-value in the default and empirical dataset over time $[28,33]$

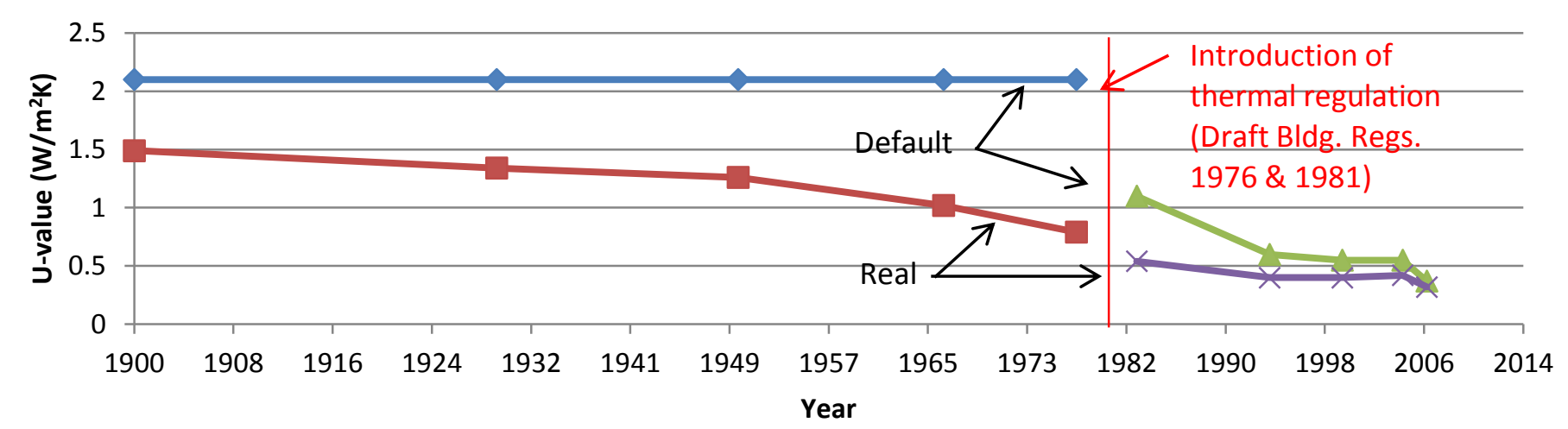

Fig. 7 Roof $U$-value in the default and empirical dataset over time [28, 33]

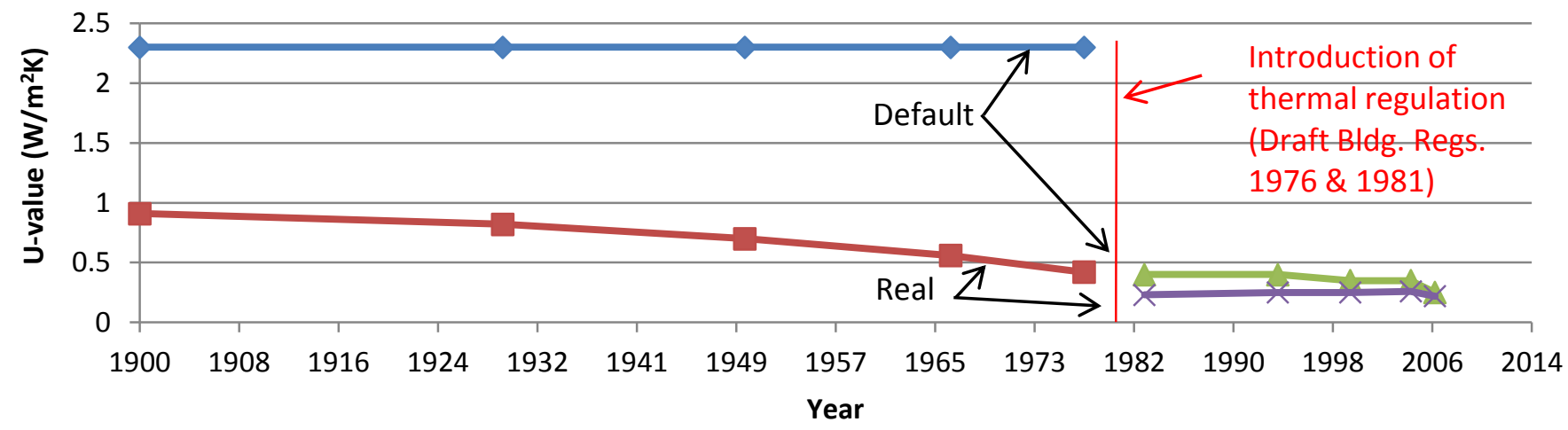


Fig. 8 Basis of typical pay-back period calculation arising from thermal retrofits

\section{Benchmark building}

(variable) not

typically based on

statistical distribution
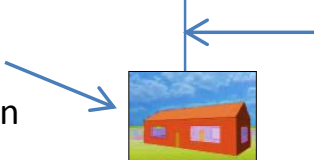
Current basis of advised payback
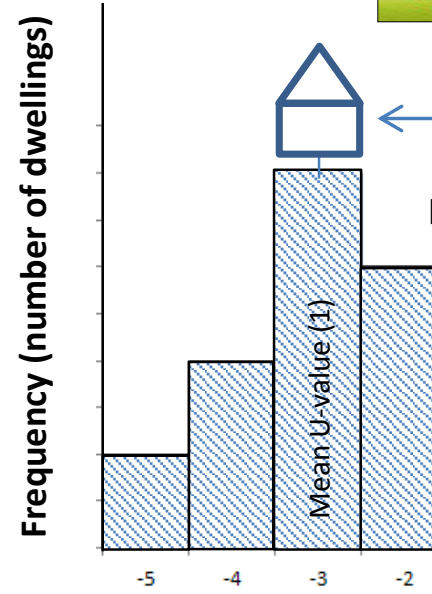
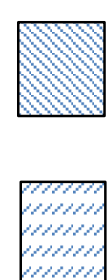

Mode 1 - Thermally upgraded building element

Mode 2 - As built building element 
Table 1 Building energy rating and payback periods for two identical buildings with and without information [5]

\begin{tabular}{|c|c|c|c|c|}
\hline & & $\begin{array}{c}\text { Default } \\
\text { U-value } \\
\text { employed? }\end{array}$ & $\begin{array}{c}\text { Building } \\
\text { Energy Rating }\end{array}$ & $\begin{array}{l}\text { Payback period for } \\
\text { thermal upgrade } \\
\text { measures }\end{array}$ \\
\hline \multirow{2}{*}{ 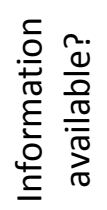 } & Yes & No & High & Realistic \\
\hline & No & Yes & Low & $\begin{array}{c}\text { Unrealistically } \\
\text { short }\end{array}$ \\
\hline
\end{tabular}

Table 2 Irish Building Regulation Summary [27]

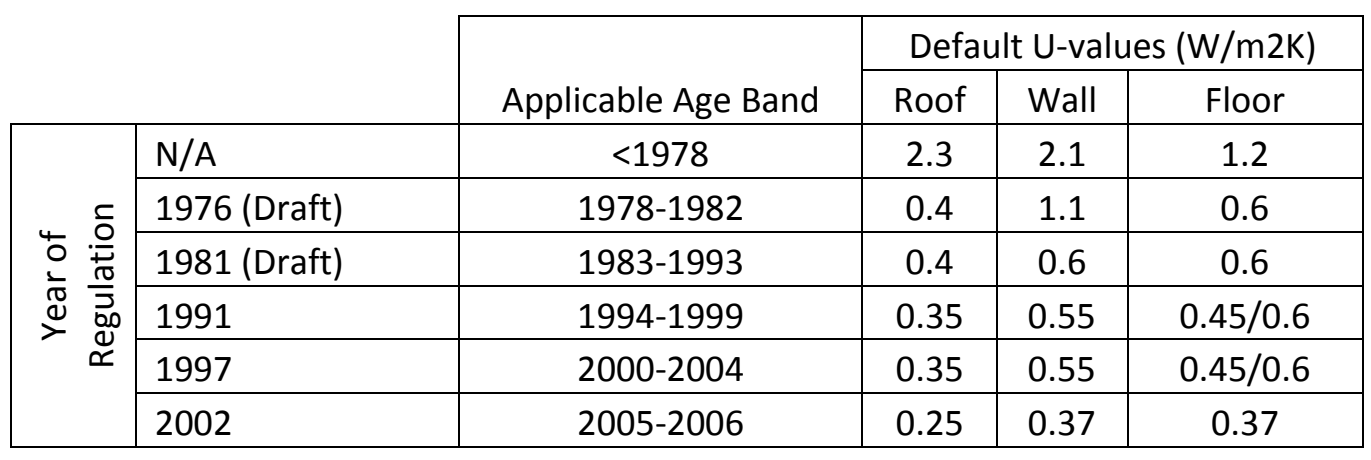


Table 3 Frequency of detached dwellings in representative empirical dataset compared with actual dwelling frequency by period of construction $[33,38]$

\begin{tabular}{|c|c|c|c|c|c|}
\hline \multirow{2}{*}{\multicolumn{2}{|c|}{ Period of Construction }} & \multicolumn{2}{|c|}{$\begin{array}{c}\text { Frequency } \\
\text { detached } \\
\text { building } \\
\text { typology } \\
\text { nationally }\end{array}$} & \multicolumn{2}{|c|}{$\begin{array}{c}\text { Frequency } \\
\text { empirical } \\
\text { dataset }\end{array}$} \\
\hline & & $\mathrm{N}$ & $\%$ & $\mathrm{~N}$ & $\%$ \\
\hline \multirow{5}{*}{ 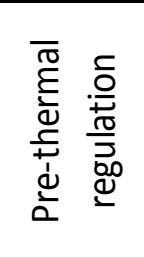 } & $<1900$ & 44784 & $11 \%$ & 1294 & $3 \%$ \\
\hline & $1900-1929$ & 34552 & $8 \%$ & 2901 & $8 \%$ \\
\hline & $1930-1949$ & 32453 & $8 \%$ & 2110 & $7 \%$ \\
\hline & 1950-1966 & 32245 & $8 \%$ & 3662 & $11 \%$ \\
\hline & $1967-1977$ & 52457 & $13 \%$ & 6559 & $13 \%$ \\
\hline \multirow{5}{*}{ 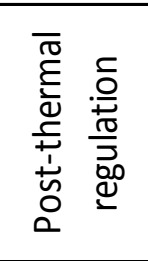 } & $1978-1982$ & 29817 & $7 \%$ & 5695 & $19 \%$ \\
\hline & $1983-1993$ & 60233 & $15 \%$ & 8375 & $14 \%$ \\
\hline & 1994-1999 & 45694 & $11 \%$ & 7080 & $15 \%$ \\
\hline & $2000-2004$ & 52764 & $13 \%$ & 8867 & $17 \%$ \\
\hline & $2005-2006$ & 21910 & $5 \%$ & 3693 & $17 \%$ \\
\hline & & 406909 & $100 \%$ & 50236 & $11 \%$ \\
\hline
\end{tabular}

Table 4 Implication of default U-value selection on Energy Performance Certification

\begin{tabular}{|c|c|c|c|c|c|c|c|}
\hline 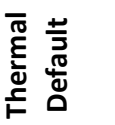 & $\begin{array}{c}\text { Very } \\
\text { Optimistic }\end{array}$ & Optimistic & $\begin{array}{l}\text { Moderately } \\
\text { Optimistic }\end{array}$ & Realistic & $\begin{array}{l}\text { Moderately } \\
\text { Pessimistic }\end{array}$ & Pessimistic & $\begin{array}{c}\text { Very } \\
\text { Pessimistic }\end{array}$ \\
\hline 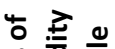 & \multirow{2}{*}{\multicolumn{4}{|c|}{ Loss of Validity }} & \multicolumn{3}{|l|}{ Loss of Validity } \\
\hline s & & & & & Slight & & Significant \\
\hline 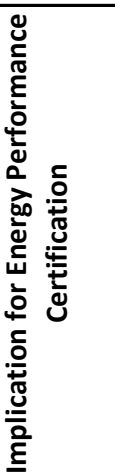 & \multicolumn{3}{|c|}{$\begin{array}{l}\text { Increasing loss of accuracy leading to an } \\
\text { increasingly significant risk that, } \\
\text { a) improvement measures could } \\
\text { actually worsen the energy rating rather } \\
\text { than make it better and, b) } \\
\text { assessors and end-users might be less } \\
\text { motivated to gather detailed } \\
\text { information about the building where it } \\
\text { is not readily available. }\end{array}$} & $\begin{array}{l}\text { Using statistical means determined } \\
\text { empirically shall significantly } \\
\text { increase the statistical accuracy of } \\
\text { the performance certificate } \\
\text { however if the realistic value is too } \\
\text { optimistic for the particular } \\
\text { building being examined without } \\
\text { information, it may lead to an } \\
\text { underestimation of the potential to } \\
\text { improve the energy performance } \\
\text { rating }\end{array}$ & \multicolumn{3}{|c|}{$\begin{array}{l}\text { Increasing loss of accuracy leading to an } \\
\text { increasingly significant risk of, } \\
\begin{array}{ll}\text { a) the results returned by the process greatly } \\
\text { overestimating the potential savings from the } \\
\text { retrofit intervention and } & \text { b) a } \\
\text { punitive system, especially for existing } \\
\text { buildings. }\end{array}\end{array}$} \\
\hline
\end{tabular}


Table 5 Percentage of walls and roofs which have been significantly thermally retrofitted and/or upgraded by period of construction [33]

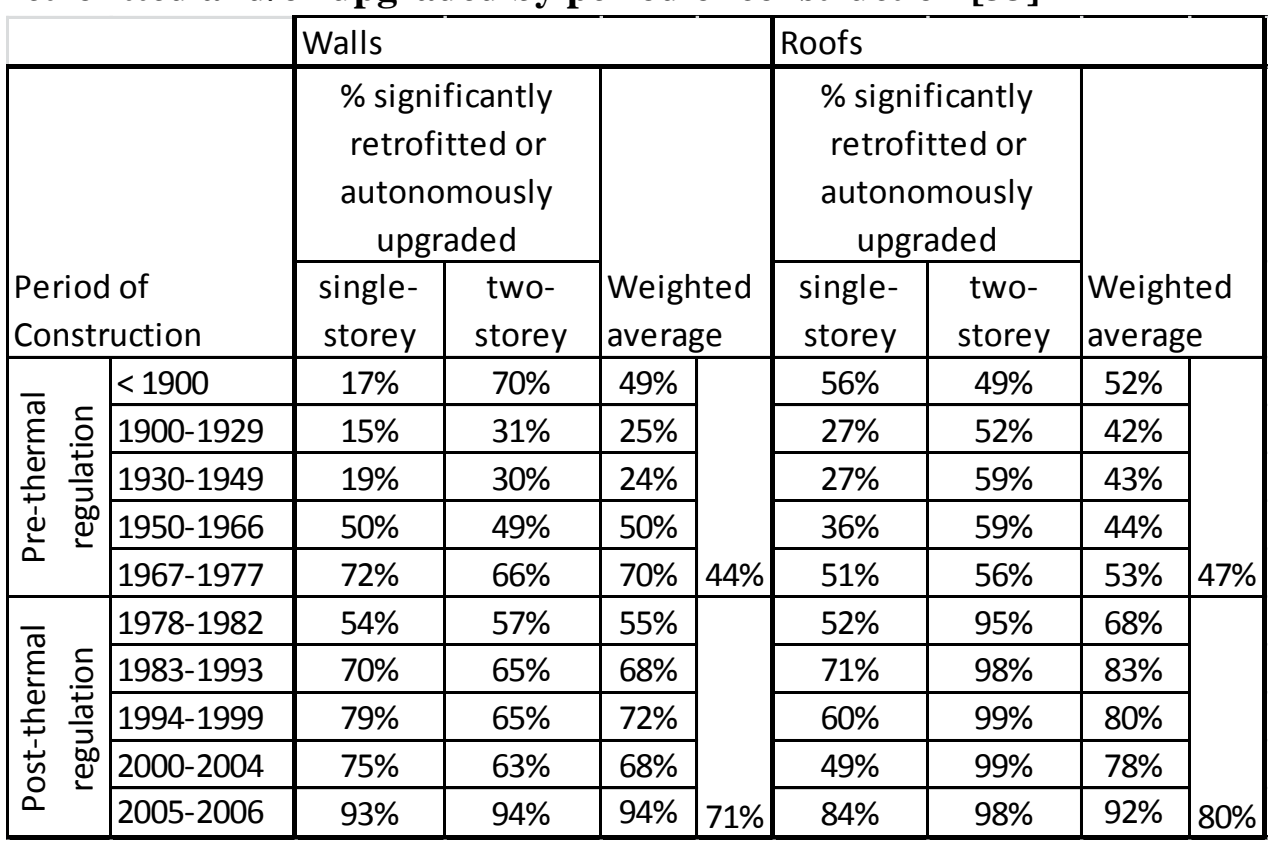

Table 6 Recommendation of empirically derived default U-values for detached Irish dwellings [33]

\begin{tabular}{|c|c|c|c|c|c|c|c|c|c|c|c|c|c|c|c|}
\hline \multirow{3}{*}{\multicolumn{2}{|c|}{$\begin{array}{c}\text { Period of } \\
\text { Construction }\end{array}$}} & \multicolumn{7}{|c|}{ Wall } & \multicolumn{7}{|c|}{ Roof } \\
\hline & & \multirow{3}{*}{$\begin{array}{r}\text { Current } \\
\text { Default } \\
2.10 \\
\end{array}$} & \multicolumn{3}{|c|}{$\begin{array}{l}\text { Recommended single- } \\
\text { storey default }\end{array}$} & \multicolumn{3}{|c|}{$\begin{array}{c}\text { Recommended two- } \\
\text { storey default }\end{array}$} & \multirow{2}{*}{$\begin{array}{l}\text { Current } \\
\text { Default }\end{array}$} & \multicolumn{3}{|c|}{$\begin{array}{l}\text { Recommended single- } \\
\text { storey default }\end{array}$} & \multicolumn{3}{|c|}{$\begin{array}{l}\text { Recommended two- } \\
\text { storey default }\end{array}$} \\
\hline & & & \multirow{2}{*}{$\begin{array}{c}\begin{array}{c}\text { U-value } \\
\left(\mathrm{W} / \mathrm{m}^{2} \mathrm{~K}\right)\end{array} \\
1.92 \\
\end{array}$} & \multicolumn{2}{|c|}{ RSD (\%)* } & \multirow{2}{*}{\begin{tabular}{|c|}
$\begin{array}{c}\text { U-value } \\
\left(\mathrm{W} / \mathrm{m}^{2} \mathrm{~K}\right)\end{array}$ \\
2.09 \\
\end{tabular}} & \multicolumn{2}{|c|}{ RSD (\%)* } & & \multirow{2}{*}{$\begin{array}{c}\begin{array}{c}\text { U-value } \\
\left(\mathrm{W} / \mathrm{m}^{2} \mathrm{~K}\right)\end{array} \\
1.40\end{array}$} & \multicolumn{2}{|c|}{ RSD (\%)* } & \multirow{2}{*}{\begin{tabular}{|c}
$\begin{array}{c}\text { U-value } \\
\left(\mathrm{W} / \mathrm{m}^{2} \mathrm{~K}\right)\end{array}$ \\
1.62
\end{tabular}} & \multicolumn{2}{|c|}{ RSD (\%)* } \\
\hline \multirow{5}{*}{ 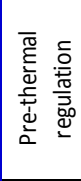 } & $>1900$ & & & $-9 \%$ & \multirow{5}{*}{$-10 \%$} & & $0 \%$ & \multirow{5}{*}{$8 \%$} & 2.30 & & $-39 \%$ & \multirow{5}{*}{$-60 \%$} & & $-30 \%$ & \multirow{5}{*}{$-38 \%$} \\
\hline & 1900-1929 & 2.10 & 1.83 & $-13 \%$ & & 1.86 & $-11 \%$ & & 2.30 & 1.13 & $-51 \%$ & & 1.58 & $-31 \%$ & \\
\hline & 1930-1949 & 2.10 & 2.08 & $-1 \%$ & & 2.02 & $-4 \%$ & & 2.30 & 1.00 & $-57 \%$ & & 1.43 & $-38 \%$ & \\
\hline & $1950-1966$ & 2.10 & 1.89 & $-10 \%$ & & 1.89 & $-10 \%$ & & 2.30 & 0.61 & \begin{tabular}{|l|}
$-73 \%$ \\
\end{tabular} & & 1.32 & $-43 \%$ & \\
\hline & $1967-1977$ & 2.10 & 1.78 & $-15 \%$ & & 1.78 & $\mid-15 \%$ & & 2.30 & 0.50 & $-78 \%$ & & 1.21 & $-47 \%$ & \\
\hline \multirow{5}{*}{ 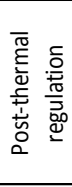 } & $1978-1982$ & 1.10 & 0.77 & \begin{tabular}{|l|}
$-30 \%$ \\
\end{tabular} & \multirow{5}{*}{$-19 \%$} & 0.94 & \begin{tabular}{|l|}
$-14 \%$ \\
\end{tabular} & \multirow{5}{*}{$-7 \%$} & 0.40 & 0.36 & \begin{tabular}{|l|}
$-10 \%$ \\
\end{tabular} & \multirow{5}{*}{$+/-11 \%$} & 0.34 & \begin{tabular}{|l|}
$-15 \%$ \\
\end{tabular} & \multirow{5}{*}{$+/ 10 \%$} \\
\hline & 1983-1993 & 0.60 & 0.57 & $-5 \%$ & & 0.58 & $-3 \%$ & & 0.40 & 0.30 & $-25 \%$ & & 0.36 & $-11 \%$ & \\
\hline & 1994-1999 & 0.55 & 0.45 & $-18 \%$ & & 0.53 & $-4 \%$ & & 0.35 & 0.35 & $0 \%$ & & 0.35 & $0 \%$ & \\
\hline & 2000-2004 & 0.55 & 0.42 & $-24 \%$ & & 0.53 & $-4 \%$ & & 0.35 & 0.40 & $14 \%$ & & 0.38 & $9 \%$ & \\
\hline & 2005-2006 & 0.37 & 0.31 & $\mid-16 \%$ & & 0.34 & \begin{tabular}{|l|}
$-9 \%$ \\
\end{tabular} & & 0.25 & 0.24 & $\mid-6 \%$ & & 0.28 & $13 \%$ & \\
\hline
\end{tabular}

